\title{
Primary Cutaneous T-Cell/Histiocyte-Rich Large B-Cell Lymphoma
}

National Cancer Institute

\section{Source}

National Cancer Institute. Primary Cutaneous T-Cell/Histiocyte-Rich Large B-Cell

Lymphoma. NCl Thesaurus. Code C45215.

T-Cell/histiocyte-rich large B-cell lymphoma that arises from the skin. 